\title{
The Production of Hydrogen Sulphide from Thiosulphate by Escherichia coli
}

\author{
BY M. ARTMAN \\ Department of Bacteriology, Hebrew University-Hadassah Medical School, \\ Jerusalem, Israel
}

\begin{abstract}
SUMMARY: Suspensions of non-proliferating Escherichia coli produced $\mathrm{H}_{2} \mathrm{~S}$ from thiosulphate in the presence of pyruvate or acetaldehyde. Production of $\mathbf{H}_{2} \mathrm{~S}$ was slight in the presence of $\alpha$-ketoglutarate and $\alpha$-ketobutyrate. Organic acids such as malate, fumarate, succinate, lactate, formate and acetate, aldehydes other than acetaldehyde and monohydric alcohols either had no effect or inhibited $\mathrm{H}_{2} \mathrm{~S}$ production from thiosulphate. $\mathrm{H}_{2} \mathrm{~S}$ was not produced from sulphite, bisulphite or sulphate, either in the presence or in the absence of the above-named compounds. Crude cellfree extracts of Escherichia coli produced $\mathrm{H}_{2} \mathrm{~S}$ from thiosulphate in the presence of pyruvate. Experiments with dialysed extracts showed that inorganic phosphate, $\mathrm{Mg}$ ions and cocarboxylase were essential for $\mathrm{H}_{2} \mathrm{~S}$ production. Treatment of the extracts with anion exchange resin revealed that in addition, coenzyme $A$ was indispensable for $\mathrm{H}_{2} \mathrm{~S}$ production from thiosulphate. The addition of DPN to extracts dialysed or treated with anion exchange resin did not influence $\mathrm{H}_{2} \mathrm{~S}$ production to a marked degree.
\end{abstract}

Suspensions of non-proliferating cells of various species of Enterobacteriaceae produce $\mathrm{H}_{2} \mathrm{~S}$ in the presence of such sulphur-containing compounds as cysteine and thiosulphate. The work carried out in this field by many authors has been recently reviewed by Clarke (1953) and by Olitzki (1954). While quantitative differences in the intensity of $\mathrm{H}_{2} \mathrm{~S}$ production by different micro-organisms are well known, no data exist which explain the mechanism of their $\mathbf{H}_{2} \mathrm{~S}$ production from inorganic sulphur compounds. The purpose of the present study was to examine the factors governing $\mathbf{H}_{2} \mathrm{~S}$ production from thiosulphate by nonproliferating organisms and cell-free extracts of Escherichia coli.

\section{METHODS}

Preparation of suspensions of non-proliferating organisms

Escherichia coli strain $\mathbf{B} / \mathbf{r}$ was used throughout. The organisms were grown on Difco nutrient agar in Roux bottles. The $18 \mathrm{hr}$. growth was washed off with distilled water, washed twice in phosphate buffer $(\mathrm{pH} 6 \cdot 8)$ and the suspension brought to the required density as measured in the Coleman Junior spectrophotometer at a wavelength of $550 \mathrm{~m} \mu$.

Preparation of cell-free extracts. The organisms were grown as described above. After harvesting and centrifugation they were washed in distilled water and subjected to sonic vibration for 15-20 min. in a Raytheon Magnetostriction Oscillator and then centrifuged at 10,000 r.p.m. for $10 \mathrm{~min}$. The cell-free supernatant solution was used in all experiments. Protein was determined by the 
biuret method of Mehl (1945), using a Coleman Junior spectrophotometer at $\mathbf{5 4 0} \mathrm{m} \mu$.

Treatment with anion exchange resin. The anion exchange resin 'Amberlite' Ira 410 was charged with $4 \%(\mathrm{w} / \mathrm{v})$ sodium chloride until the $\mathrm{pH}$ of the effluent was neutral. The resin was then washed with distilled water until no chloride could be detected in the effluent. The resin was added directly to the extracts in equal volume, the suspension stirred for $15 \mathrm{~min}$., centrifuged and the supernatant finally filtered to remove the last traces of resin. This treatment removed coenzyme $\mathbf{A}$ as judged by arsenolysis (Stadtman, Novelli \& Lipmann, 1951). The cocarboxylase was removed by the same procedure.

Experimental procedure. Sodium thiosulphate was brought in contact with a cell suspension or cell-free extracts in the presence of sodium phosphate buffer (pH 6.8) and incubated at $37^{\circ}$ in small test tubes closed with a rubber stopper to prevent any losses of $\mathrm{H}_{2} \mathrm{~S}$. After the required incubation, the reaction was stopped by the addition of two drops of $20 \%$ sodium hydroxide and sulphide determined by the method of Delwiche (1951).

\section{RESULTS}

Optimal conditions for $\mathrm{H}_{2} \mathrm{~S}$ production from thiosulphate. Suspensions of nonproliferating organisms were incubated with different amounts of sodium thiosulphate and the quantities of $\mathrm{H}_{2} \mathrm{~S}$ produced were determined after 2 and $24 \mathrm{hr}$. of incubation. Under the specified conditions the optimum amount of thiosulphate was about $800 \mu$ mole (Table 1). The optimum $\mathrm{pH}$ was of the order of $6 \cdot 8$ (Fig. 1).

Enhancement of $\mathrm{H}_{2} \mathrm{~S}$ production by glucose. Since Braun \& Silberstein (1942) reported that fermentable carbohydrates enhance the production of $\mathrm{H}_{2} \mathrm{~S}$ from inorganic sulphur compounds by growing organisms, this effect was tested by using non-proliferating cells. Glucose markedly enhanced $\mathrm{H}_{2} \mathrm{~S}$ production from thiosulphate (Fig. 2), but of several fermentable carbohydrates tested only glucose increased $\mathrm{H}_{2} \mathrm{~S}$ production, and this to a marked degree (Table 2).

The influence of inhibitors of glycolysis on $\mathrm{H}_{2} \mathrm{~S}$ production from thiosulphate. To ascertain whether glucose itself or some intermediary product arising from glucose by glycolysis was responsible for the enhancing effect in $\mathrm{H}_{2} \mathrm{~S}$ production, various known inhibitors of glycolysis were tested. These experiments showed that the various inhibitors reduced or completely arrested $\mathrm{H}_{2} \mathrm{~S}$ production (Table 3). The almost complete inhibition of $\mathrm{H}_{2} \mathrm{~S}$ production from thiosulphate by bisulphite, both in the presence and absence of glucose, suggested that the enhancing effect of glucose on $\mathbf{H}_{2} \mathrm{~S}$ production was due to pyruvic acid or some lower intermediary compound produced in the course of glycolysis, since bisulphite is known to give addition compounds with aldehydes and some ketones. The production of $\mathrm{H}_{2} \mathrm{~S}$ from thiosulphate by non-proliferating cells in the absence of glucose may thus be explained by the presence of endogenic substrate. Further evidence that without pyruvate there was no $\mathrm{H}_{2} \mathrm{~S}$ production was obtained in studies with cell-free extracts. Experiments carried out with pyruvic acid showed that this compound strongly stimulated 
Table 1. $\mathrm{H}_{2} \mathrm{~S}$ production from thiosulphate by non-proliferating

Escherichia coli

\begin{tabular}{|c|c|c|c|}
\hline $\begin{array}{l}\text { Bacterial suspension } \\
\text { (organisms/ml.) }\end{array}$ & $\begin{array}{l}\text { Thiosulphate } \\
(\mu \text { mole. })\end{array}$ & $\begin{array}{l}\text { Incubation } \\
\text { (hr.) }\end{array}$ & $\begin{array}{r}\text { produce } \\
(\mu \text { mole })\end{array}$ \\
\hline $2.5 \times 10^{8}$ & 800 & 2 & 0 \\
\hline $2.5 \times 10^{8}$ & 800 & 24 & 0 \\
\hline $2.5 \times 10^{8}$ & 500 & 2 & 0 \\
\hline $2.5 \times 10^{8}$ & 500 & 24 & 0 \\
\hline $2.5 \times 10^{8}$ & 200 & 2 & 0 \\
\hline $2.5 \times 10^{8}$ & 200 & 24 & 0 \\
\hline $2.5 \times 10^{8}$ & 100 & 2 & 0 \\
\hline $2.5 \times 10^{8}$ & 100 & 24 & 0 \\
\hline $2.5 \times 10^{9}$ & 800 & 2 & $0 \cdot 20$ \\
\hline $2.5 \times 10^{9}$ & 800 & 24 & $0 \cdot 60$ \\
\hline $2.5 \times 10^{9}$ & 500 & 2 & $0 \cdot 15$ \\
\hline $2.5 \times 10^{9}$ & 500 & 24 & $0 \cdot 45$ \\
\hline $2.5 \times 10^{9}$ & 200 & 2 & $0 \cdot 10$ \\
\hline $2.5 \times 10^{9}$ & 200 & 24 & 0.40 \\
\hline $2.5 \times 10^{9}$ & 100 & 2 & $0 \cdot 10$ \\
\hline $2.5 \times 10^{9}$ & 100 & 24 & $0 \cdot 40$ \\
\hline $1.25 \times 10^{10}$ & 800 & 2 & $0 \cdot 30$ \\
\hline $1.25 \times 10^{10}$ & 800 & 24 & $2 \cdot 00$ \\
\hline $1.25 \times 10^{10}$ & 500 & 2 & $0 \cdot 20$ \\
\hline $1.25 \times 10^{10}$ & 500 & 24 & $1 \cdot 20$ \\
\hline $1.25 \times 10^{10}$ & 200 & 2 & $0 \cdot 11$ \\
\hline $1.25 \times 10^{10}$ & 200 & 24 & $1 \cdot 00$ \\
\hline $1.25 \times 10^{10}$ & 100 & 2 & $0 \cdot 11$ \\
\hline $1.25 \times 10^{10}$ & 100 & 24 & $0 \cdot 70$ \\
\hline
\end{tabular}

Each tube contained: sodium phosphate buffer (pH 6.8), $100 \mu$ mole; cells and thiosulphate as indicated; total vol., $4 \mathrm{ml}$.

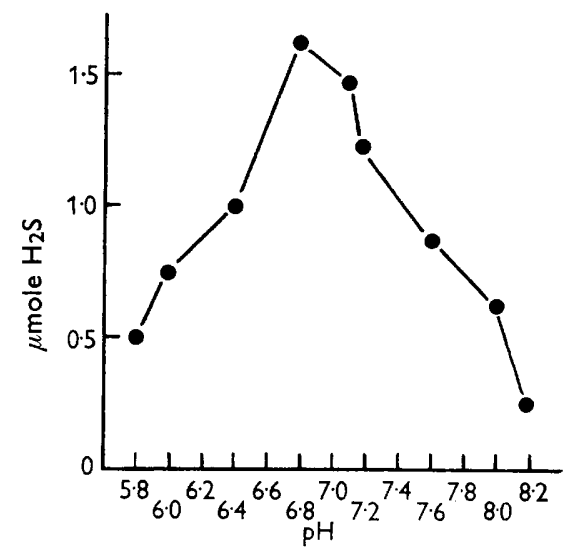

Fig. 1

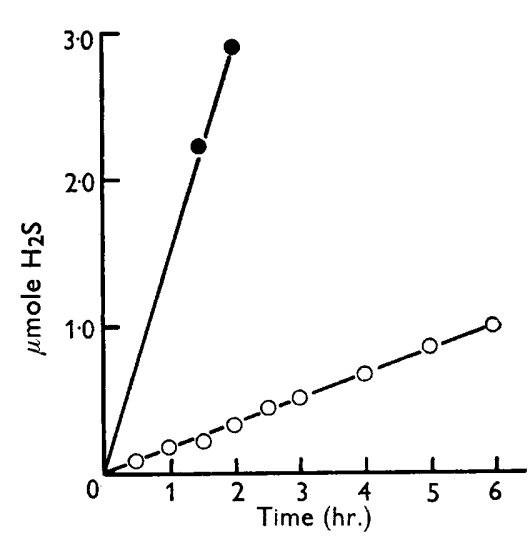

Fig. 2

Fig. 1. Effect of $\mathrm{pH}$ value on $\mathbf{H}_{2} \mathrm{~S}$ production from thiosulphate by non-proliferating Escherichia coli. Organism concentration $1.25 \times 10^{10} / \mathrm{ml}$; thiosulphate, $800 \mu \mathrm{mole}$; sodium phosphate buffer of various $\mathrm{pH}$ values, $100 \mu$ mole; final vol., $4 \mathrm{ml}$; time of incubation, $4 \mathrm{hr}$.

Fig. 2. The effect of glucose on $\mathrm{H}_{2} \mathrm{~S}$ production from thiosulphate by non-proliferating Escherichia coli. The reaction mixture contained: glucose, when added, $100 \mu$ mole; thiosulphate, $800 \mu$ mole; sodium phosphate buffer (pH 6.8), $100 \mu$ mole; organism concentration $1.25 \times 10^{10}$; final vol., $4 \mathrm{ml}$. $-\mathrm{O}^{-} \mathrm{-}-$, without glucose; - - - - , with glucose. 
$\mathrm{H}_{2} \mathrm{~S}$ production and the magnitude of this effect was equal to that obtained with equimolar glucose. As expected, the production of $\mathrm{H}_{2} \mathrm{~S}$ in the presence of pyruvate was not affected by fluoride, in contrast to the results obtained with glucose.

Table 2. Effect of various fermentable carbohydrates on $\mathbf{H}_{2} \mathrm{~S}$ production by non-proliferating Escherichia coli

$\begin{array}{cc}\begin{array}{c}\text { Carbohydrates } \\ (100 \mu \text { mole })\end{array} & \begin{array}{c}\mathrm{H}_{2} \mathrm{~S} \text { produced } \\ (\mu \mathrm{mole})\end{array} \\ \text { Glucose } & \mathbf{2 \cdot 7 0} \\ \text { Maltose } & 0 \cdot 27 \\ \text { Lactose } & 0 \cdot 30 \\ \text { Sucrose } & \mathbf{0 \cdot 3 3} \\ \text { Galactose } & 0 \cdot 33 \\ \text { Xylose } & \mathbf{0 \cdot 2 7} \\ \text { None } & \mathbf{0 \cdot 3 3}\end{array}$

Each vessel contained: carbohydrates as indicated; thiosulphate, $800 \mu$ mole; sodium phosphate buffer (pH 6.8), $100 \mu$ mole; organism concentration, $1.25 \times 10^{10} / \mathrm{ml}$; final vol., $4 \mathrm{ml}$. $\mathrm{H}_{2} \mathrm{~S}$ determined after $2 \mathrm{hr}$. at $37^{\circ}$.

Table 3. The effect of glycolysis inhibitors on $\mathrm{H}_{2} \mathrm{~S}$ production from thiosulphate in the presence and absence of glucose

\begin{tabular}{|c|c|c|c|c|c|}
\hline \multirow[b]{2}{*}{ Inhibitors } & \multirow[b]{2}{*}{$\begin{array}{c}\text { Concentrations } \\
\text { (M) }\end{array}$} & \multicolumn{2}{|c|}{ Glucose present } & \multicolumn{2}{|c|}{ Glucose absent } \\
\hline & & $\begin{array}{c}\mathbf{H}_{2} \mathbf{S} \\
(\mu \text { mole })\end{array}$ & $\begin{array}{c}\text { Inhibition } \\
(\%)\end{array}$ & $\begin{array}{c}\mathbf{H}_{2} \mathbf{S} \\
(\mu \text { mole })\end{array}$ & $\begin{array}{c}\text { Inhibition } \\
(\%)\end{array}$ \\
\hline Na bisulphite & 0.01 & $0 \cdot 10$ & 96 & o & 100 \\
\hline Na bisulphite & 0.001 & $0 \cdot 36$ & 89 & $\mathbf{0}$ & 100 \\
\hline Na fluoride & 0.01 & $0 \cdot 33$ & 90 & 0.40 & - \\
\hline Na fluoride & $0 \cdot 001$ & 0.73 & 78 & $0 \cdot 40$ & - \\
\hline $\mathrm{Na}$ iodoacetate & $0 \cdot 01$ & $0 \cdot 20$ & 94 & $0 \cdot 20$ & 50 \\
\hline $\mathrm{Na}$ iodoacetate & 0.001 & $0 \cdot 30$ & 91 & $0 \cdot 20$ & 50 \\
\hline None & & $\mathbf{3 \cdot 2 0}$ & - & $0 \cdot 40$ & - \\
\hline
\end{tabular}

Each reaction mixture contained : thiosulphate, $800 \mu$ mole; Na phosphate buffer (pH 6.8), $100 \mu$ mole; glucose, when present, $100 \mu$ mole; inhibitors as indicated. Concentration of organisms, $25 \times 10^{10} / \mathrm{ml}$; ; total vol. $44 \mathrm{ml}$. Sulphide determined after $3 \mathrm{hr}$.

The effect of various organic acids and alcohols on $\mathrm{H}_{2} \mathrm{~S}$ production from thiosulphate. Results of the above experiments suggested that $\mathrm{H}_{2} \mathrm{~S}$ production from thiosulphate is conditioned by the presence of hydrogen donors and thus the effect of adding various hydrogen donors was examined. The results of these experiments (Table 4) showed, surprisingly, that none of the compounds tested enhanced the production of $\mathrm{H}_{2} \mathrm{~S}$ from thiosulphate. The following organic acids and alcohols were without effect, whether in the presence or absence of glucose: succinate, acetate, formate, lactate, citrate, methanol and propanol. Butanol had a marked inhibitory effect. Malate and fumarate inhibited the reaction completely in the absence of glucose. This result may be tentatively explained by the prevention of endogenic pyruvate formation due to the inhibition of oxaloacetate decarboxylation to pyruvate by malate (Ochoa \& Weisz-Tabori, 1948). The same explanation is valid in the case of fumarate 
since these acids are readily interconvertible. Another interesting observation that arose from the above experiments was that ethanol in the presence of glucose almost doubled $\mathrm{H}_{2} \mathrm{~S}$ production. Further experiments showed that only ethanol (among other alcohols examined) enhanced $\mathbf{H}_{2} \mathbf{S}$ production from thiosulphate, and then only in the presence of glucose or pyruvate. Ethanol alone or in the presence of all the above-mentioned organic acids had no effect.

Table 4. The effect of various organic acids and alcohols on $\mathrm{H}_{2} \mathrm{~S}$ production from thiosulphate in the presence and absence of glucose

\begin{tabular}{|c|c|c|}
\hline \multirow[b]{2}{*}{ Organic acids and alcohols } & \multicolumn{2}{|c|}{$\mathbf{H}_{2} \mathbf{S}(\mu$ mole $)$} \\
\hline & Glucose present & Glucose absent \\
\hline None & $3 \cdot 00$ & $0 \cdot 20$ \\
\hline Pyruvate & $3 \cdot 70$ & $3 \cdot 20$ \\
\hline Fumarate & $3 \cdot 00$ & 0.00 \\
\hline Malate & $\mathbf{2 \cdot 9 0}$ & $0 \cdot 00$ \\
\hline Acetate & $\mathbf{2 \cdot 9 0}$ & $0 \cdot 20$ \\
\hline Formate & $3 \cdot 00$ & $0 \cdot 19$ \\
\hline Lactate & 3.00 & $0 \cdot 20$ \\
\hline Succinate & $2 \cdot 90$ & $0 \cdot 20$ \\
\hline Citrate & $3 \cdot 00$ & $0 \cdot 20$ \\
\hline$\alpha$-Ketoglutarate & $3 \cdot 70$ & $0 \cdot 43$ \\
\hline$\alpha$-Ketobutyrate & $3 \cdot 30$ & 0.53 \\
\hline Methanol & $3 \cdot 00$ & $0 \cdot 20$ \\
\hline Ethanol & $6 \cdot 00$ & $0 \cdot 30$ \\
\hline Propanol & $\mathbf{2 \cdot 3 0}$ & $0 \cdot 20$ \\
\hline Butanol & $2 \cdot 00$ & $0 \cdot 10$ \\
\hline
\end{tabular}

Experimental conditions as given in Table 3. The organic acids were neutralized with sodium hydroxide to $\mathrm{pH} 6.8$ prior to addition. Organic acids and alcohols, when added, $100 \mu$ mole. $\mathrm{H}_{2} \mathrm{~S}$ determined after $3 \mathrm{hr}$.

If an intermediary compound responsible for $\mathrm{H}_{2} \mathrm{~S}$ production arises it might give rise to ethanol, and addition of ethanol would then cause accumulation of the intermediary compound and thus enhance $\mathrm{H}_{2} \mathrm{~S}$ production. Although the fermentation processes in Escherichia coli leading from pyruvate to acetaldehyde are not known, these experiments suggest that acetaldehyde may be the intermediary compound responsible for $\mathrm{H}_{2} \mathrm{~S}$ production from thiosulphate, since acetaldehyde enhanced $\mathrm{H}_{2} \mathrm{~S}$ production to the same degree as glucose or pyruvate (Table 5). Among the inhibitors of glycolysis only bisulphite inhibited $\mathrm{H}_{2} \mathrm{~S}$ production. No other aldehydes had any stimulatory effect on $\mathrm{H}_{2} \mathrm{~S}$ production; on the contrary, higher aldehydes from 4-C exerted an inhibitory effect.

$\mathrm{H}_{2} \mathrm{~S}$ production from various inorganic compounds. Experiments carried out with bisulphite, sulphite and sulphate in the presence and absence of various carbohydrates, organic acids, alcohols and aldehydes, showed no production of $\mathrm{H}_{2} \mathrm{~S}$.

$\mathrm{H}_{2} \mathrm{~S}$ production from thiosulphate by crude cell-free extracts. Production of $\mathrm{H}_{2} \mathrm{~S}$ from thiosulphate by crude extracts took place only in the presence of pyruvate. In the presence of glucose little if any $\mathrm{H}_{2} \mathrm{~S}$ was produced. There was 
no $\mathrm{H}_{2} \mathrm{~S}$ production from thiosulphate in the presence of various organic acids and alcohols.

$\mathrm{H}_{2} \mathrm{~S}$ production by dialysed extracts. Cell-free extracts after dialysis against distilled water for $18 \mathrm{hr}$. in a cold room at $5^{\circ}$ failed to produce $\mathrm{H}_{2} \mathrm{~S}$ from thiosulphate in the presence of pyruvate unless $\mathrm{Mg}$ ions, cocarboxylase and inorganic phosphate were added. The addition of DPN with the abovementioned cofactors had no appreciable effect on $\mathrm{H}_{2} \mathrm{~S}$ production (Table 6).

Table 5. (a) The effect of various aldehydes on $\mathrm{H}_{2} \mathrm{~S}$ production from thiosulphate. (b) The effect of inhibitors of glycolysis on $\mathrm{H}_{2} \mathrm{~S}$ production from thiosulphate in the presence of acetaldehyde
Aldehydes
Inhibitors of glycolysis
$\mathbf{H}_{2} \mathrm{~S}$ ( $\mu$ mole)
$2 \cdot 00$
$0 \cdot 00$
(a) Formaldehyde

\begin{tabular}{ll}
- & $0 \cdot 20$ \\
- & $\mathbf{2} 00$ \\
\hline & $0 \cdot 10$
\end{tabular}
Acetaldehyde
Propylaldehyde Butylaldehyde
(b) Acetaldehyde
Acetaldehyde
Acetaldehyde
Acetaldehyde
Na fluoride $0 \cdot 01 \mathrm{M} \quad 2 \cdot 30$
Na fluoride $0 \cdot 001 \mathrm{M} \quad \mathbf{2 \cdot 3 0}$
Na bisulphite $0.01 \mathrm{M} \quad 0.00$
Na bisulphite $0.001 \mathrm{M} \quad 0.00$

Each test tube contained: thiosulphate, $800 \mu$ mole; aldehydes, $80 \mu$ mole; sodium phosphate buffer (pH 6.8), $100 \mu$ mole; organism concentration $1.25 \times 10^{10} / \mathrm{ml}$; inhibitors as indicated; final vol., $4 \mathrm{ml} . \mathrm{H}_{2} \mathrm{~S}$ determined after $2 \mathrm{hr}$. at $37^{\circ}$.

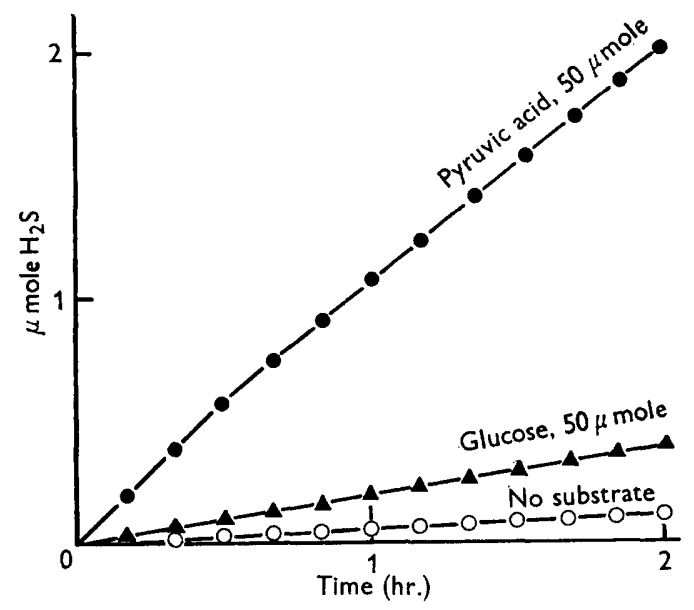

Fig. 3. $\mathbf{H}_{2} \mathrm{~S}$ production from thiosulphate by crude extracts of Escherichia coli. Each test tube contained: extract containing $20 \mathrm{mg}$. protein; thiosulphate, $300 \mu$ mole; sodium phosphate buffer (pH 6.8), $100 \mu$ mole; total vol., $3 \mathrm{ml}$.

$\mathrm{H}_{2} \mathrm{~S}$ production by extracts treated with anion exchange resin. These extracts, after treatment with anion exchange resin, did not produce $\mathrm{H}_{2} \mathrm{~S}$ from thiosulphate in the presence of pyruvate unless $\mathbf{M g}$ ions, cocarboxylase, inorganic phosphate and coenzyme $\mathrm{A}$ were added. The addition of DPN with the abovementioned activators did not affect $\mathbf{H}_{2} \mathrm{~S}$ production appreciably. A typical 
experiment is shown in Table 7. In the presence of $\alpha$-ketoglutarate the results were similar to those obtained with pyruvate, but the amount of $\mathrm{H}_{2} \mathrm{~S}$ produced was considerably smaller.

Table 6. $\mathrm{H}_{2} \mathrm{~S}$ production from thiosulphate by dialysed extracts

$\begin{array}{lcc}\text { Cofactors } & \begin{array}{c}\text { Inorganic } \\ \text { phosphate }\end{array} & \mathrm{H}_{2} \mathrm{~S}(\mu \text { mole }) \\ \text { Control before dialysis } & \text { Added } & 2 \cdot 10 \\ \text { None } & \text { None } & 0 \cdot 00 \\ \text { None } & \text { Added } & 0 \cdot 10 \\ \mathrm{MgCl}_{2} \text {, cocarboxylase } & \text { Added } & \mathbf{1} \cdot 80 \\ \mathrm{MgCl}_{2}, \text { cocarboxylase, DPN } & \text { Added } & \mathbf{1 \cdot 6 0}\end{array}$

Each vessel contained: extracts containing $20 \mathrm{mg}$. protein; thiosulphate, $300 \mu$ mole; pyruvate, $50 \mu$ mole ; cocarboxylase, when added, $200 \mu \mathrm{g}$.; $\mathrm{MgCl}_{2}$, if added, $32 \mu \mathrm{mole}$; veronal

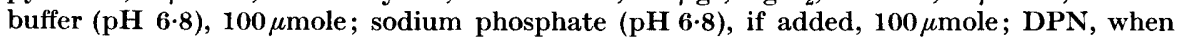
added, $200 \mu \mathrm{g}$.; total vol., $3 \mathrm{ml}$. $\mathbf{H}_{2} \mathrm{~S}$ determined after $2 \mathrm{hr}$. at $37^{\circ}$.

Table 7. $\mathrm{H}_{2} \mathrm{~S}$ production from thiosulphate in the presence of pyruvate by extracts treated with anion exchange resin

\begin{tabular}{|c|c|c|}
\hline Cofactors & Phosphate & $\begin{array}{c}\mathbf{H}_{2} \mathbf{S} \text { produced } \\
(\mu \text { mole })\end{array}$ \\
\hline None & Added & $0 \cdot 23$ \\
\hline $\mathrm{MgCl}_{2}$, cocarboxylase & None & $0 \cdot 29$ \\
\hline $\begin{array}{l}\mathrm{MgCl}_{2} \text {, cocarboxylase, } \\
\text { coenzyme } \mathrm{A}, \mathrm{DPN}\end{array}$ & None & $0 \cdot 31$ \\
\hline $\begin{array}{c}\mathrm{MgCl}_{2} \text {, cocarboxylase, } \\
\text { coenzyme A, DPN }\end{array}$ & Added & $1 \cdot 61$ \\
\hline $\begin{array}{l}\mathrm{MgCl}_{2} \text {, coenzyme } \mathrm{A}, \\
\text { cocarboxylase }\end{array}$ & Added & 1.91 \\
\hline $\mathrm{MgCl}_{2}$, coenzyme $\mathrm{A}$ & Added & $0 \cdot 69$ \\
\hline Untreated control & Added & $2 \cdot 30$ \\
\hline
\end{tabular}

Experimental conditions as given in Table 6. Coenzyme A, when added, 30 units.

\section{DISCUSSION}

The exact mechanism involved in $\mathrm{H}_{2} \mathrm{~S}$ production from thiosulphate still remains to be elucidated. The requirement for pyruvate (pyruvate could be replaced to some extent by $\alpha$-ketoglutarate and $\alpha$-ketobutyrate, and in nonproliferating cell suspensions by acetaldehyde) as well as for some of the cofactors of the pyruvic dehydrogenase system seems to indicate that $\mathrm{H}_{2} \mathrm{~S}$ formation from thiosulphate is linked to a reductive step, in which pyruvate serves as an obligate hydrogen donor. The specificity of the hydrogen donor appears remarkable. It will be recalled in this connexion that the oxidation of pyruvate in bacteria requires thioctic acid as a primary hydrogen acceptor (reviewed by Gunsalus, 1953). If the formula of thiosulphate is written as follows:

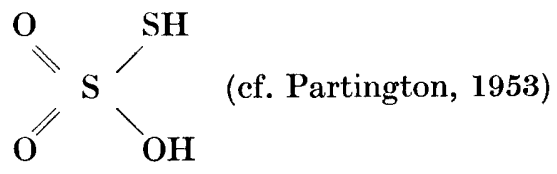


the presence of an $\mathbf{S}-\mathrm{S}$ bond becomes apparent. It is tempting to speculate that the $\mathbf{S}-\mathbf{S}$ bond confers on the thiosulphate the capacity to function as a primary hydrogen acceptor, alternative to thioctic acid. This interpretation would readily account for the specificity of hydrogen donor, the failure of other inorganic sulphur compounds to produce $\mathrm{H}_{2} \mathrm{~S}$, and the finding that the system mediating $\mathrm{H}_{2} \mathrm{~S}$ production from thiosulphate, in contrast to pyruvic dehydrogenase, does not depend on DPN as an essential cofactor. It will be pointed out that, according to the scheme of Gunsalus (1954), DPN serves to regenerate the $\mathbf{S}-\mathbf{S}$ linkage of the reduced thioctic acid. In the reaction described by me the acceptor (thiosulphate) is supplied in excess and therefore the regeneration mechanism is obviously not required.

I wish to express my gratitude to Prof. A. L. Olitzki for having suggested to me the subject of the study, and for constant guidance and encouragement throughout this work, which forms part of a study submitted for the degree of Ph.D. to the Senate of the Hebrew University.

\section{REFERENCES}

Braun, H. \& Silberstein, W. (1942). Über die Bedingungen der Schwefelwasserstoffbildung bei Darmbacterien. Rev. Fac. Sci. Istanbul. B, 7, 1.

Clarke, P. H. (1953). Hydrogen sulphide production by bacteria. J.gen. Microbiol. $8,397$.

Delwiche, E. (1951). Activators for the cysteine desulphydrase system of Escherichia coli mutant. J. Bact. 62, 717.

Gunsalus, J. C. (1953). The chemistry and function of the pyruvate oxidation factor (lipoic acid). J. cell. comp. Physiol. 41, suppl. 1, 113.

Gunsalus, J. C. (1954). Oxidative and transfer reactions of lipoic acid. Fed. Proc. $13,715$.

Menr, J. W. (1945). The biuret reaction of proteins in the presence of ethylene glycol. J. biol. Chem. 154, 173.

OchoA, S. \& Weisz-TABORI, E. (1948). Biosynthesis of tricarboxylic acids by carbon dioxide fixation. J. biol. Chem. 174, 123.

Olitzкi, A. L. (1954). Hydrogen sulphide production by non multiplying organisms and its inhibition by antibiotics. J. gen. Microbiol. 11, 160.

Partington, J. R. (1953). A Text-Book of Inorganic Chemistry, 6th ed. p. 488. London: Macmillan and Co. Ltd.

Stadtman, E. R., Novelit, D. \& Lipmann, F. (1951). Coenzyme A function in and acetyl transfer by the phosphotransacetylase system. J. biol. Chem. 191, 365 . 